\title{
The role of endoscopic ultrasound and endoscopic resection for gastric glomus: A case series and literature review
}

\author{
Jinlong Hu, Nan Ge, Sheng Wang, Xiang Liu, Jintao Guo, Guoxin Wang, Siyu Sun
}

Endoscopy Center, Shengjing Hospital of China Medical University, Shenyang, Liaoning Province, China

\section{ABSTRACT}

Background and Objectives: Preoperative diagnosis of gastric glomus tumor is very difficult, and there are few reports regarding the endoscopic treatment of glomus tumor of the stomach. Our aim is to provide a retrospective assessment of the imaging features of endoscopic ultrasound (EUS) and treatment of choice of gastric glomus tumor. Methods: A database of all patients with gastric glomus tumor who was treated at Shengjing Hospital of China Medical University between March 2011 and March 2017 was retrospectively analyzed. The EUS characteristics and patients' clinical data as well as their treatment were reviewed. At the same time, we compared EUS characteristics of gastric glomus tumor with that of gastrointestinal stromal tumor (GISTs), leiomyomas, schwannomas, and ectopic pancreas. Results: Eleven patients ( 3 male and 8 female patients) were included in the present study. The patients' age ranged from 37 to 62 years (mean age, 50.1 years). Ten patients received EUS examination. Eight lesions were presented with mild-hyperechoic round or oval mass; one lesion was mild-hyperechoic oval mass with hypoechoic spots; one lesion was hypoechoic oval mass. One patient received endoscopic full-thickness resection; 3 patients were treated by endoscopic submucosal dissection; and laparoscopic resection was performed for 7 patients. Conclusions: Gastric glomus has typical EUS features to differentiate from other submucosal tumors. Compared with surgery, endoscopic resection is also a safe and effective treatment of choice for gastric glomus tumor.

Key words: endoscopic ultrasound, glomus tumor, endoscopic full-thickness resection, endoscopic submucosal dissection

\section{INTRODUCTION}

Address for Correspondence: Prof. Siyu Sun, M.D., PHD, Endoscopy Center, Shengjing Hospital of China Medical University, Shenyang 110004

Liaoning Province, China.

E-mail: sun-siyu@163.com

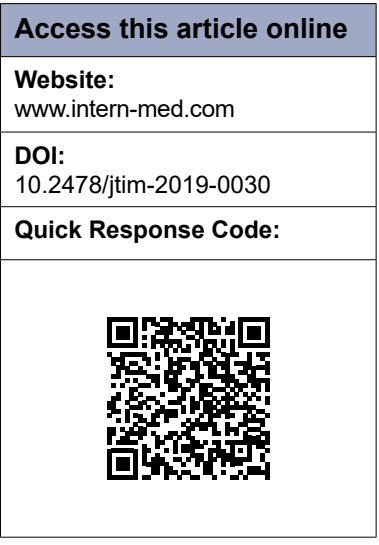

Glomus tumor is a rare vascular tumor originating from glomus bodies. Although most of glomus tumors occur in the distal extremities, this can also occur in any part of body ${ }^{[1]}$ In the gastrointestinal tract, glomus tumors are most commonly located in the stomach and present as submucosal tumors. ${ }^{[2]}$ Although glomus tumors are generally benign in nature, several malignant cases have been reported. ${ }^{[3-5]}$ Most of the gastric glomus tumors are asymptomatic and are incidentally discovered; sometimes it may present with gastrointestinal hemorrhage and abdominal pain. ${ }^{[6]}$ Many glomus tumors of the stomach, however, are misdiagnosed as other mesenchymal tumors, such as gastrointestinal stromal tumors (GISTs) and leiomyomas. Therefore, it is of paramount importance to accurately preoperative diagnose gastric glomus tumors. Endoscopic ultrasound (EUS) is a useful imaging technique for diagnosing the gastric submucosal tumors, ${ }^{[7-9]}$ but only a few case reports have been published regarding the characteristics of gastric glomus tumors. ${ }^{[10]}$

Surgical resection is a curable treatment for gastric glomus tumor. With the development of endoscopic equipment, endoscopic methods, such as endoscopic submucosal dissection (ESD) and endoscopic fullthickness resection (EFTR), have been widely used for gastric submucosal tumors. However, there were few articles regarding 
endoscopic resection of gastric glomus tumors, which might be due to its vascular nature. Thus, our aim is to describe the typical EUS features and endoscopic resection of gastric glomus tumors.

\section{PATIENTS AND METHODS}

\section{Patients}

A database of all patients with gastric glomus tumor who were treated at Shengjing Hospital of China Medical University between March 2011 and March 2017 was retrospectively analyzed.

At the same time, we reviewed the EUS characteristics of GISTs, leiomyomas, ectopic pancreas, and schwannomas in patients. The EUS characteristics and patients' clinical data as well as their treatment were reviewed. The study was approved by the Ethics Committee of China Medical University and all the patients signed written informed consent.

\section{Methods}

\section{Endoscopic ultrasound}

All EUS procedures were performed with a linear scanning ultrasound endoscope. A single experienced endosonographer reviewed all the EUS images. The following features were recorded: location, the presence of mucosal ulceration, shape, original layer, echogenicity, the presence of marginal halos, cystic change, and calcification. At the same time, we compared EUS characteristics with that of GISTs, leiomyomas, schwannomas, and ectopic pancreas.

\section{Treatment}

\section{ESD}

All ESD procedures were performed with propofol sedation and continuous cardiorespiratory monitoring. ESD was performed as follows: the circumferential of the tumor was marked by argon plasma coagulation (APC), and then, a cushion was made by injection of a mixed solution consisting of $100-\mathrm{mL}$ saline and $1-\mathrm{mL}$ indigo carmine. After the mucosa incision was made, dissection of the tumor was made. The hemostasis was performed by electric cautery or APC.

\section{EFTR}

The peritumor gastric tissues were incised, and then, the tumor and peritumor gastric tissues were gradually resected in full thickness and electric cautery was used for hemostasis. Then, the tumor was completely removed. Metallic clips or over-the-scope clip was used to close the iatrogenic perforation.

\section{Laparoscopic resection and surgical resection}

Laparoscopic resection and surgical resection were performed as previously reported.

\section{Postoperative follow-up}

Patients were suggested for the follow-up at 1, 3, 6, and 12 months after resection and annually thereafter to observe the wound healing and any residual tumor or recurrence.

\section{RESULTS}

\section{Clinical data of patients}

The clinical data for 11 patients $(3$ male and 8 female patients) were included in the present study and were summarized in table 1 . The patients' age ranged from 37 to 62 years (mean age, 50.1 years). Seven patients had epigastric discomfort, two patients had abdominal pain, one patient had abdominal distension, and one patient presented as upper gastrointestinal bleeding.

The characteristics of the lesion and EUS findings

Ten patients received EUS. The EUS characteristics of 10 patients with gastric glomus tumors was presented in Table 1. Nine lesions were located in antrum and two tumors were found in the gastric body. All the lesions presented as a submucosal tumor and one lesion had an ulcer on its surface (Figure 1), leading to hemorrhage. The maximum size of tumors ranged from 10 to $35 \mathrm{~mm}$ with mean size being 19 $\mathrm{mm}$. Nine lesions were from fourth layer, and one lesion was from third and fourth layers. Eight lesions were presented with mild-hyperechoic round or oval mass (Figure 2); one lesion was mild-hyperechoic oval mass with hypoechoic spots; one lesion was hypoechoic oval mass with a clear border. Ten patients with gastric GISTs located in gastric antrum, 10 patients with gastric leiomyoma located in gastric antrum. 10 patients with gastric schwannoma located in gastric antrum, and 10 patients with gastric ectopic pancreas located in gastric antrum were randomly selected. The EUS features of gastric glomus tumors were compared with that of gastric GISTs, leiomyoma, schwannoma, and ectopic pancreas, as shown in Table 2. The typical EUS feature of gastric glomus tumor is a triad: antrum; round or oval; mildhyperechoic lesion from fourth layer.

\section{Treatment}

One patient received EFTR; three patients were treated by ESD, and laparoscopic resection was performed for seven patients. Complete resection was performed in all the patients. No complications, such as delayed perforation and hemorrhage, occurred in any patients. Nine patients had the pathology of glomus tumor; two patients had pathology of glomus tumor with uncertain malignant potential, as shown in Table 3.

\section{Follow-up}

No recurrence or metastases were found in all patients during the follow-up period at a median follow-up time of 32 months (range, 3-62 months). 
Hu et al: :Endoscopic features of gastric glomus tumor

\begin{tabular}{|c|c|c|c|c|c|c|c|}
\hline No. & Age/Sex & Symptom & $\begin{array}{l}\text { Size of tumor } \\
(\mathrm{mm})\end{array}$ & Location & $\begin{array}{l}\text { Endoscopic } \\
\text { appearance }\end{array}$ & EUS layer & EUS appearance \\
\hline 1 & $38 / \mathrm{male}$ & Abdominal pain & 19 & $\begin{array}{l}\text { Greater curvature of } \\
\text { antrum }\end{array}$ & SMT & Fourth & Mild-hyperechoic round mass \\
\hline 2 & $62 /$ female & $\begin{array}{l}\text { Abdominal } \\
\text { discomfort }\end{array}$ & 10 & $\begin{array}{l}\text { Greater curvature of } \\
\text { gastric body }\end{array}$ & SMT & Fourth & Mild-hyperechoic round mass \\
\hline 3 & $56 /$ female & $\begin{array}{l}\text { Abdominal } \\
\text { discomfort }\end{array}$ & 11 & Anterior wall of antrum & SMT & Fourth & Hypoechoic oval mass \\
\hline 4 & $52 /$ female & Abdominal pain & 27 & Posterior wall of antrum & SMT & Fourth & Mild-hyperechoic oval mass \\
\hline 5 & $59 /$ female & $\begin{array}{l}\text { Abdominal } \\
\text { discomfort }\end{array}$ & 27 & Posterior wall of antrum & SMT & Fourth & Mild-hyperechoic round mass \\
\hline 6 & $48 /$ female & UGH & 35 & Gastric body & $\begin{array}{l}\text { SMT with a } \\
\text { ulcer on the } \\
\text { surface }\end{array}$ & Third, Fourth & $\begin{array}{l}\text { Mild-hyperechoic oval mass } \\
\text { with hypoechoic spots }\end{array}$ \\
\hline 7 & $47 /$ female & $\begin{array}{l}\text { Abdominal } \\
\text { discomfort }\end{array}$ & 12 & $\begin{array}{l}\text { Greater curvature of } \\
\text { antrum }\end{array}$ & SMT & Fourth & Mild-hyperechoic round mass \\
\hline 8 & $56 /$ male & $\begin{array}{l}\text { Abdominal } \\
\text { distension }\end{array}$ & 28 & $\begin{array}{l}\text { Greater curvature of } \\
\text { antrum }\end{array}$ & SMT & Fourth & Mild-hyperechoic oval mass \\
\hline 9 & $50 /$ male & $\begin{array}{l}\text { Abdominal } \\
\text { discomfort }\end{array}$ & 27 & $\begin{array}{l}\text { Greater curvature of } \\
\text { antrum }\end{array}$ & SMT & - & - \\
\hline 10 & $37 /$ female & $\begin{array}{l}\text { Abdominal } \\
\text { discomfort }\end{array}$ & 22 & Anterior wall of antrum & SMT & Fourth & Mild-hyperechoic round mass \\
\hline 11 & $46 /$ female & $\begin{array}{l}\text { Abdominal } \\
\text { discomfort }\end{array}$ & 20 & $\begin{array}{l}\text { Greater curvature of } \\
\text { antrum }\end{array}$ & SMT & Fourth & Mild-hyperechoic round mass \\
\hline
\end{tabular}

SMT, submucosal tumor.

\begin{tabular}{|c|c|c|c|c|c|c|c|}
\hline $\begin{array}{l}\text { Tumor type(case } \\
\text { number) }\end{array}$ & $\begin{array}{l}\text { Mean size } \\
\text { (range), } \mathrm{mm}\end{array}$ & Layer & Shape & Echogenicity & Marginal halo & $\begin{array}{l}\text { Cystic } \\
\text { change }\end{array}$ & Calcification \\
\hline Glomus tumor (10) & $19(10-35)$ & $\begin{array}{l}\text { Nine lesions were from } \\
\text { fourth layer; one lesion } \\
\text { was from third, fourth } \\
\text { layer }\end{array}$ & $\begin{array}{l}\text { Ten lesions were } \\
\text { round or oval } \\
\text { shape }\end{array}$ & $\begin{array}{l}\text { Nine lesions } \\
\text { were mild- } \\
\text { hyperechoic; } \\
\text { one lesion was } \\
\text { hypoechoic }\end{array}$ & No & $\begin{array}{l}\text { One lesion } \\
\text { had cystic } \\
\text { change }\end{array}$ & No \\
\hline GIST (10) & $18(12-42)$ & $\begin{array}{l}\text { Ten lesions were from } \\
\text { fourth layer }\end{array}$ & $\begin{array}{l}\text { Ten lesions were } \\
\text { oval shape }\end{array}$ & Hypoechoic & No & No & $\begin{array}{l}3 \text { lesions had } \\
\text { calcification }\end{array}$ \\
\hline Leiomyoma (10) & $14(10-36)$ & $\begin{array}{l}\text { Ten lesions were from } \\
\text { fourth layer }\end{array}$ & $\begin{array}{l}\text { Ten lesions were } \\
\text { oval shape }\end{array}$ & Hypoechoic & No & No & No \\
\hline Schwannoma (10) & $18(12-25)$ & $\begin{array}{l}\text { Ten lesions were from } \\
\text { fourth layer }\end{array}$ & $\begin{array}{l}\text { Ten lesions were } \\
\text { oval shape }\end{array}$ & Hypoechoic & $\begin{array}{l}\text { Four lesions } \\
\text { had marginal } \\
\text { halo }\end{array}$ & No & No \\
\hline Ectopic pancreas (10) & $13(8-23)$ & $\begin{array}{l}\text { Nine lesions were from } \\
\text { third layer; one lesion } \\
\text { was from third, fourth } \\
\text { layer }\end{array}$ & $\begin{array}{l}\text { Eight lesions } \\
\text { were flat shape; } \\
\text { two lesions } \\
\text { were oval shape }\end{array}$ & Mixed-echoic & No & No & No \\
\hline
\end{tabular}

\section{DISSCUSSION}

Gastric glomus tumors are rare with a significant female dominance. ${ }^{[2]}$ Most of the gastric glomus tumor are located in antrum. ${ }^{[6]}$ We got similar results as previously reported. Patients with gastric glomus tumor can present different symptoms, such as abdominal discomfort or pain, and gastric glomus tumor is one of rare causes of gastrointestinal hemorrhage. ${ }^{[1-14]}$ One patient $(1 / 11)$ presented with upper gastrointestinal bleeding in our report.
Preoperative diagnosis of gastric glomus tumor is the key point for the treatment. Glomus tumors, GISTs, schwannomas, and neuro-endocrine tumors, however, exhibit similar findings on computed tomography, making it difficult to differentiate glomus tumor from other tumors. ${ }^{[15-18]}$ Moreover, some cases of glomus tumor of the stomach do not show the typical characteristics on CT. With EUS being widely used, ${ }^{[19-21]}$ EUS is of great importance for differential diagnosis of gastric submucosal tumor. In our report, the typical EUS features of glomus tumor of the stomach can be listed as follows: the lesion is located 
Hu et al::Endoscopic features of gastric glomus tumor

\begin{tabular}{|c|c|c|c|c|c|c|}
\hline No & Treatment & Patology & $\begin{array}{l}\text { Postoperative } \\
\text { bleeding }\end{array}$ & $\begin{array}{l}\text { Postoperative } \\
\text { perforation }\end{array}$ & Recurrence & Follow-up, month \\
\hline 1 & ESD & Glomus tumor & No & No & No & 3 \\
\hline 2 & ESD & Glomus tumor & No & No & No & 62 \\
\hline 3 & ESD & Glomus tumor & No & No & No & 48 \\
\hline 4 & EFTR & Glomus tumor & No & No & No & 60 \\
\hline 5 & Laparoscopy & Glomus tumor & No & No & No & 61 \\
\hline 6 & Laparoscopy & $\begin{array}{l}\text { Glomus tumor with } \\
\text { uncertain malignant } \\
\text { potential }\end{array}$ & No & No & No & 18 \\
\hline 7 & Laparoscopy & Glomus tumor & No & No & No & 56 \\
\hline 8 & Laparoscopy & $\begin{array}{l}\text { Glomus tumor with } \\
\text { uncertain malignant } \\
\text { potential }\end{array}$ & No & No & No & 24 \\
\hline 9 & Laparoscopy & Glomus tumor & No & No & No & 32 \\
\hline 10 & Laparoscopy & Glomus tumor & No & No & No & 6 \\
\hline 11 & Laparoscopy & Glomus tumor & No & No & No & 12 \\
\hline
\end{tabular}

ESD: endoscopic submucosal dissection; EFTR: endoscopic full-thickness resection.

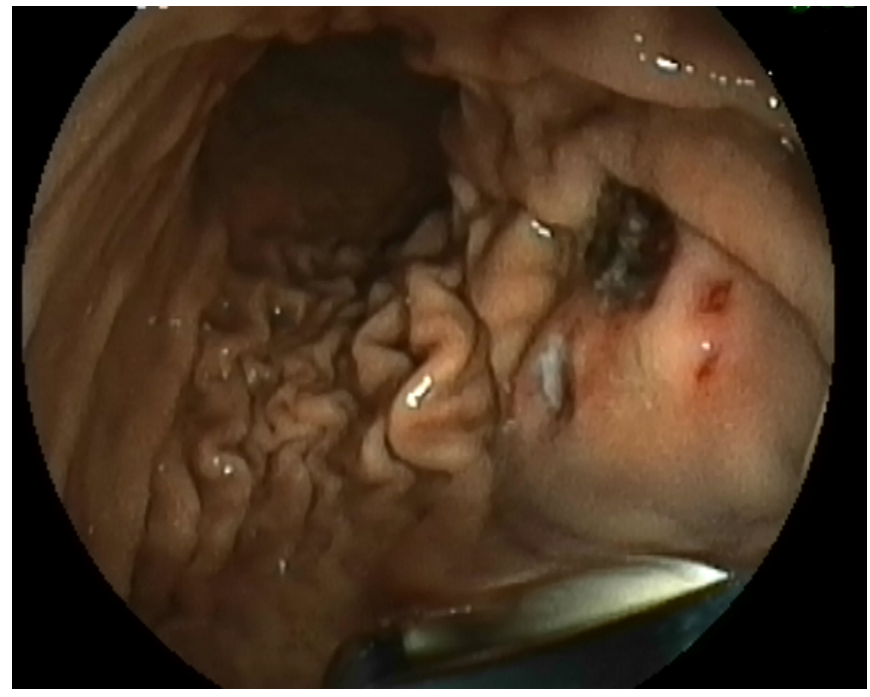

Figure 1: Gastric glomus lesion presenting as a submucosal tumor, with an ulcer on its surface

in antrum; its shape is round or oval on EUS; it is a mildhyperechoic lesion from fourth layer. Hu et al. reported that gastric glomus tumors were oval $(n=4)$ and round $(n=6)$ in shape. ${ }^{[22]}$ The mild-hyperechogenicity may be due to its vascular nature. Yan $e t$ al. reported that Doppler EUS showed a prominent vascular signal in gastric glomus tumor. ${ }^{[23]}$ The typical EUS features of glomus tumor of the stomach were described in some reports. ${ }^{\left[{ }^{[6,24-26]}\right.}$ Nine patients $(9 / 11)$ were presented with typical EUS features. Two lesions did not have the typical EUS features. One lesion was hypoechoic and one lesion was from third and fourth layer. Compared with other common gastric submucosal tumor, such as GISTs, leiomyoma, ectopic pancreas, and schwannoma, the typical EUS features of glomus tumor of the stomach can make the differential diagnosis. Some gastric glomus tumor with atypical EUS

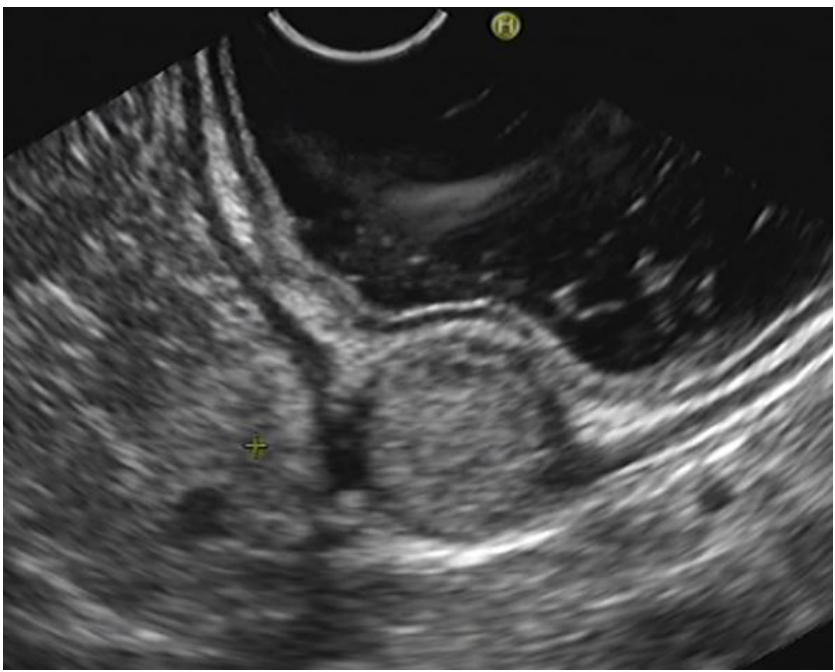

Figure 2: Gastric glomus lesions presented with mild-hyperechoic round or oval mass

features is still difficult to differentiate on EUS. EUS elastography and contrast-enhanced EUS can provide more information. ${ }^{[27-31]}$ In addition, endoscopic ultrasound guided fine needle aspiration (EUS-FNA) can help in diagnosis. ${ }^{[32-34]}$ Although glomus tumor is a vascular lesion, it is safe to perform EUS-FNA. No complications, such as bleeding, happen. Few reports had demonstrated that gastric glomus tumor could be diagnosed by EUS-FNA. ${ }^{[10,35-39]}$

Glomus tumors are mesenchymal tumors with malignant potential. ${ }^{[00-42]}$ Although most of glomus tumor of stomach are benign, some malignant cases have been reported. ${ }^{[3-5,43]}$ In our study, there were two patients diagnosed with glomus tumor with uncertain malignant potential. So resection is the only curative therapy with a favorable prognosis for benign glomus tumor. 
Traditionally, surgery is the first choice of treatment for gastric glomus tumor. ${ }^{[25,44,45]}$ Endoscopic resection, such as ESD and EFTR, are being increasingly used in treating gastric submucosal tumors. ${ }^{[4-48]}$ However, to the best of our knowledge, there is rare report that gastric glomus tumor was treated by endoscopic resection, ${ }^{[49]}$ which may be due to its rarity and its vascular nature. Four patients in our study were treated by ESD or EFTR, and there was no fatal bleeding. During the follow-up, there was no residual tumor and no recurrence.

\section{CONCLUSIONS}

The typical EUS feature of glomus tumor of the stomach is that a round or an oval mild-hyperechoic lesion originating from fourth layer is located in antrum. Endoscopic resection is a safe and effective treatment of choice for gastric glomus tumor.

\section{Conflict of Interest}

None declared.

\section{REFERENCES}

1. Tsuneyoshi M, Enjoji M. Glomus tumor: a clinicopathologic and electron microscopic study. Cancer 1982;50:1601-7.

2. Miettinen M, Paal E, Lasota J, Sobin LH. Gastrointestinal glomus tumors: a clinicopathologic, immunohistochemical, and molecular genetic study of 32 cases. Am J Surg Pathol 2002;26:301-11.

3. Zaidi S, Arafah M. Malignant Gastric Glomus Tumor: A Case Report and Literature Review of a Rare Entity. Oman Med J 2016;31:60-4.

4. Teng TH, Huang SH, Liang CW. Malignant gastric glomus tumour mimicking GIST. Pathology 2012;44:261-3.

5. Song SE, Lee CH, Kim KA, Lee HJ, Park CM. Malignant glomus tumor of the stomach with multiorgan metastases: report of a case. Surg Today 2010; 40:662-7.

6. Kang G, Park HJ, Kim JY, Choi D, Min BH, Lee JH, Kim JJ, Kim KM, Park CK, Sohn TS et al. Glomus tumor of the stomach: a clinicopathologic analysis of 10 cases and review of the literature. Gut Liver 2012;6:52-7.

7. Abad-Belando R, Varas-Lorenzo MJ, Pons-Vilardell C, Puig-Torrus X, Pla-Alcaraz M, et al. Canalization technique to obtain deep tissue biopsy of gastrointestinal subepithelial tumors as an alternative to conventional known techniques. Endosc Ultrasound 2018;7:184-90.

8. Flores A, Papafragkakis C, Uberoi AS, Thaiudom S, Bhutani MS. EUS of an atypical ectopic pancreas. Endosc Ultrasound 2018;7:216-7.

9. Gottschalk U, Dietrich CF, Jenssen C. Ectopic pancreas in the upper gastrointestinal tract: Is endosonographic diagnosis reliable? Data from the German Endoscopic Ultrasound Registry and review of the literature. Endosc Ultrasound 2018;7:270-8.

10. Kato S, Kikuchi K, Chinen K, Murakami T, Kunishima F. Diagnostic utility of endoscopic ultrasound-guided fine-needle aspiration biopsy for glomus tumor of the stomach. World J Gastroenterol 2015; 21:7052-8.

11. Morte D, Bingham J, Sohn V. Gastric Glomus Tumor: An Uncommon Source for an Acute Upper GI Bleed. Case Rep Gastrointest Med 2018; 2018:7961981.

12. Alkhormi AM, Memon MY, Alqarawi A. Gastric Antral Vascular Ectasia: A Case Report and Literature Review. J Transl Int Med 2018;6:47-51.
13. Laeeq SM, Tasneem AA, Hanif FM, Luck NH, Mandhwani R, Wadhva R. Upper Gastrointestinal Bleeding in Patients with End Stage Renal Disease: Causes, Characteristics and Factors Associated with Need for Endoscopic Therapeutic Intervention. J Transl Int Med 2017;5:106-11.

14. Qi X, Li H, Shao X, Liang Z, Zhang X, Feng J, et al. Should Vasoconstrictors be Considered in a Cirrhotic Patient with Acute Non-variceal Upper Gastrointestinal Bleeding? J Transl Int Med 2017;5:240-4.

15. Hur BY, Kim SH, Choi JY, Rha SE, Lee MW, Kim SY, et al. Gastroduodenal glomus tumors: differentiation from other subepithelial lesions based on dynamic contrast-enhanced CT findings. AJR Am J Roentgenol 2011;197:1351-9.

16. Kim SH. [Gastric glomus tumor showing hepatic hemangioma-like enhancement pattern on CT]. Korean J Gastroenterol 2011;57:134-7.

17. Patel TH, Horton KM, Hruban RH, Fishman EK. Glomus Tumor of the Stomach: Depiction by Multidetector CT and Three-Dimensional Volume Rendering Imaging. Case Rep Med 2010;2010:126095.

18. Hu XY, Hu CH, Fang XM, Zhang TH. Glomus tumor of the gastric body: helical CT findings. Chin Med J (Engl) 2007;120:1289-91.

19. Sahai AV. EUS is trending! Endosc Ultrasound 2018; 7:353-5.

20. Rimbas M, Crino SF, Gasbarrini A, Costamagna G, Scarpa A, Larghi A. EUS-guided fine-needle tissue acquisition for solid pancreatic lesions: Finally moving from fine-needle aspiration to fine-needle biopsy? Endosc Ultrasound 2018;7:137-40.

21. Cazacu IM, Luzuriaga Chavez AA, Saftoiu A, Vilmann P, Bhutani MS. A quarter century of EUS-FNA: Progress, milestones, and future directions. Endosc Ultrasound 2018;7:141-60.

22. Hu SD, Hu DM, Huang W, Chen KM, Song Q. Computed tomography and clinical characteristics of gastric glomus tumors. J Dig Dis 2014;15:47782.

23. Yan SL, Yeh YH, Chen CH, Yang CC, Kuo CL, Wu HS. Gastric glomus tumor: a hypervascular submucosal tumor on power Doppler endosonography. J Clin Ultrasound 2007;35:164-8.

24. Baek YH, Choi SR, Lee BE, Kim GH. Gastric glomus tumor: analysis of endosonographic characteristics and computed tomographic findings. Dig Endosc 2013;25:80-3.

25. Halawani HM, Khalife M, Safadi B, Rida K, Boulos F, Khalifeh F. Laparoscopic antral resection with Billroth I reconstruction for a gastric glomus tumor. Int J Surg Case Rep 2014;5:1128-31.

26. Chou KC, Yang CW, Yen HH. Rare gastric glomus tumor causing upper gastrointestinal bleeding, with review of the endoscopic ultrasound features. Endoscopy 2010; 42 Suppl 2:E58-9.

27. Dietrich CF, Bibby E, Jenssen C, Saftoiu A, Iglesias-Garcia J, Havre RF. EUS elastography: How to do it? Endosc Ultrasound 2018;7:20-8.

28. Pesenti C, Bories E, Caillol F, Ratone JP, Godat S, Monges G, et al. Characterization of subepithelial lesions of the stomach and esophagus by contrastenhanced EUS: A retrospective study. Endosc Ultrasound 2019;8:43-9.

29. Iglesias-Garcia J, Larino-Noia J, Dominguez-Munoz JE. New diagnostic techniques for the differential diagnosis of pancreatic mass: Elastography helps me 100. Endosc Ultrasound 2017;6:S115-8.

30. Dietrich CF, Burmester E. Contrast-enhanced ultrasound of small focal solid pancreatic lesions: A must! Endoscc Ultrasound 2017;6:S106-10.

31. Costache MI, Dumitrescu D, Saftoiu A. Technique of qualitative and semiquantitative EUS elastography in pancreatic examination. Endosc Ultrasound 2017;6:S111-4.

32. Chong CCN, Teoh AYB, Tang RSY, Chan AWH, Ng EKW, Lai PBS. EUSFNA using 22G nitinol or ProCore needles without on-site cytopathology. Endosc Ultrasound 2018;7:56-60.

33. Mizuno S, Nakai Y, Isayama H, Suzuki T, Saito K, Uchino R, et al. EUSFNA of gastric cancer metastatic to the head of pancreas using a forward oblique viewing echoendoscope in a case with Roux-en-Y anatomy. Endosc Ultrasound 2018;7:420-1.

34. Yasumoto M, Okabe Y, Ishikawa H, Kisaki J, Akiba J, Naito Y, et al. A case of gastric wall implantation caused by EUS-FNA 22 months after pancreatic cancer resection. Endosc Ultrasound 2018;7:64-6. 
35. Minoda Y, Akahoshi K, Oya M, Kubokawa M, Motomura Y, Nakamura K. Gastric glomus tumor diagnosed by endoscopic ultrasound-guided fine-needle aspiration biopsy: report of a case. Fukuoka Igaku Zasshi 2014; 105:105-9.

36. Gu M, Nguyen PT, Cao S, Lin F. Diagnosis of gastric glomus tumor by endoscopic ultrasound-guided fine needle aspiration biopsy. A case report with cytologic, histologic and immunohistochemical studies. Acta Cytol 2002;46:560-6.

37. Debol SM, Stanley MW, Mallery S, Sawinski E, Bardales RH. Glomus tumor of the stomach: cytologic diagnosis by endoscopic ultrasoundguided fine-needle aspiration. Diagn Cytopathol 2003;28:316-21.

38. Akahoshi K, Oya M, Koga T, Koga H, Motomura Y, Kubokawa M, et al. Clinical usefulness of endoscopic ultrasound-guided fine needle aspiration for gastric subepithelial lesions smaller than $2 \mathrm{~cm}$. J Gastrointestin Liver Dis 2014;23:405-12.

39. Jones J, Cichowitz A, Crosthwaite GL. Endoscopic ultrasound-guided fine needle aspiration as a diagnostic tool for gastric glomus tumours. ANZ J Surg 2012;82:94.

40. Toti L, Manzia TM, Roma S, Meucci R, Blasi F, Ferlosio A, et al. Rare malignant glomus tumor of the stomach with liver metastases. Radiol Case Rep 2019;14:463-7.

41. Ugras N, Yerc IO, Yalcinkaya U, Gulcu B, Ozturk E, Yildirim C, et al. Malignant glomus tumor with oncocytic features: an unusual presentation of dysphagia. APMIS: 2015;123:613-7.

42. Dong LL, Chen EG, Sheikh IS, Jiang ZN, Huang AH, Ying KJ. Malignant glomus tumor of the lung with multiorgan metastases: case report and literature review. Onco Targets Ther 2015;8:1909-14.
43. Bray AP, Wong NA, Narayan S. Cutaneous metastasis from gastric glomus tumour. Clin Exp Dermatol. 2009;34:e719-21.

44. Aoba T, Kato T, Hiramatsu K, Shibata Y, Yoshihara M, Yamaguchi N, et al. A case of gastric glomus tumor resection using laparoscopy endoscopy cooperative surgery (LECS). Int J Surg Case Rep 2018;42:204-7.

45. Campbell MJ, Irani S, Olgac S, Chang LC. Laparoscopic resection of a gastric glomus tumor. Indian J Surg 2011;73:230-2.

46. Zhang Y, Wang X, Xiong G, Qian Y, Wang H, Liu L, et al. Complete defect closure of gastric submucosal tumors with purse-string sutures. Surg Endosc 2014;28:1844-51.

47. Guo J, Sun B, Sun S, Liu X, Wang S, Ge N, et al. Endoscopic puncturesuture device to close gastric wall defects after full-thickness resection: a porcine study. Gastrointest Endosc 2017;85:447-50.

48. Liao X, Tang A, Xiao D, Shen S, Yuan Y, Wang X. [Application of endoscopic full-thickness resection in the treatment of gastric tumors originated fromthe muscularis propria]. Zhong Nan Da Xue Xue Bao Yi Xue Ban = Journal of Central South University Medical sciences 2016;41:282-6.

49. Sun P, Lyu H, Jin Y. [Endoscopic full-thickness resection of synaptophysin-positive glomus tumor in gastric body: report of a case]. Zhonghua Bing Li Xue Za Zhi 2017;46:791-2.

How to cite this article: Hu J, Ge N, Wang S, Liu X, Guo J, Wang G, Sun $S$. The role of endoscopic ultrasound and endoscopic resection for gastric glomus: A case series and literature review. J Transl Int Med 2019; 7: 149-54. 